\title{
色彩に基づいたデザイン画像の印象語付与システム*
}

\author{
白仁田 和彦*1, 林 健一 郎*1, 大 坪 昭 文*1
}

\section{An Impression-Word-Giving System for Images Based on Colors}

\author{
Kazuhiko SHIRANITA*2, Kenichiro HAYASHI and Akifumi OTSUBO \\ ${ }^{* 2}$ Industrial Technology Center of Saga Prefecture, \\ 114 Yaemizo, Nabeshima-machi, Saga-shi, Saga, 849-0932 Japan
}

\begin{abstract}
This paper describes a method of giving impression words for images based on colors. 160 impression words are prepared, and colors which are strongly related to each of the 160 impression words are registered into the system in advance. In this system, we adopt Lab color space which is a color coordinate system and can obtain exact color difference between pixels and extract main colors of images based on the results of clustering in Lab color space. The number of main colors of an image is determined when the sum of pixels of the main colors is larger than $85 \%$ of all the pixels in the image, and the colors with the larger number of pixels are determined in ascending order. We propose a distance between the main colors and the registered colors. In this system ${ }_{m} C_{n}$ combinations of distances between $m$ colors registered in an impression words and $n$ main colors are obtained. Using the ${ }_{m} C_{n}$ distances, we calculate a minimum distance and an average distance every 160 impression words. By the comparison of the minimum distance and the average distance of each impression word, the system determines suitable impression words for the image. Experimental results show the proposed method to be effective.
\end{abstract}

Key Words: Image Processing, Pattern Recognition, Human Interface, Clustering, Impression Word

\section{1. 緒}

印刷物は，一般に発注者から提供される資料や写 真などの素材と, 言葉や色彩に基づく発注者からの 要望を受け, デザイナー自らが創造する画像や写真 などの素材とを組み合わせて製造されている. デザ イナーが行う製造作業の中で, 特に重要な作業の一 つとして, 発注者の要望に合う画像や写真を多種多 量のデータベースの中から選び出す作業がある. 従 来, デザイナーは長年蓄積してきた経験と勘に基づ いて発注者の要望に合う画像や写真の選び出し作業 を綝り返し行ってきた. しかしながら，多種多量の データベースの中から, 発注者が满足できる, 適切 な画像や写真を瞬時に選び出すことは難しく, この

\footnotetext{
* 原稿受付 2003 年 2 月 7 日.

*1 正員, 佐賀県工業技術センター（⑧49-0932 佐賀市鍋島町 大字八戸溝 114).

E-mail : shiranita@saga-itc.go.jp
}

作業のためにこれまでは多くの時間と多くの手間が かかり, 非常に効率が悪かった. 色彩や言葉に基づ き, 発注者とデザイナーとの間の意思の伝達をスム 一ズに行えるシステムが開発できれば, 画像や写真 の選び出し作業が効率化され，そのシステムは生産 現場において非常に有効な手段となると言える. そ こで, 色彩に基づき発注者とデザイナーとの間の意 思を双方向に伝達するために, 画像や写真に印象語 を付与するシステムの開発が望まれている.

色彩に基づき, 画像に印象語を付与する研究につ いては、これまでにいくつかの報告がある(1)(2). 栗田らの報告 (1) では, 絵画に対して印象語を付与 するシステムを開発しているが，付与する印象語の 数が 30 種と少ないので, 実用的なシステムとは言 い難い. 田中らの報告 ${ }^{(2)}$ では, 180 種の印象語の 中から一つの印象語を画像に付与するために、それ ぞれの印象語と関係の深い 3 色組の色彩をただ一つ 用意し，それらの色彩と画像から代表色として抽出 
した 3 色の色彩との間の距離を求め, 最小の距離値 を示す印象語をその画像に対して付与している. し かしながら, 画像によっては 3 色以上の色彩を代表 色とすることが適当な場合もあり，また印象語と色 彩との関係は一対一ではないことが示されており

(3), 実用上問題がある.

そこで，本論文では，色彩に基づき印刷物で用い る画像や写真に対して印象語を付与する方法につい て述べる. 2 章では, 画像や写真の印象について, デザイナーへの聞き取り調査の結果を述べる.この 調查結果から, 画像や写真に対する印象語付与のた めのシステム化の方針について述べる． 3 章では, 画像や写真が与える印象語の種類と, その印象語に 深く関わる色彩について述べる. 4 章では, 画像や 写真を代表する色（代表色）を抽出する方法につい て述べる. 5 章では, 画像や写真から抽出された代 表色と印象語に関係する色彩との間の距離を求める 方法について述べ, その距離に基づいて画像や写真 に対して印象語を付与する方法を述べる. 6 章では, 未知の画像に対して本方法を適用する実験を行い, 本稿において付与する印象語がデザイナーのものと よく一致することを示す.

\section{2. システム化の方針}

画像や写真を収めているデータベースの中から発 注者の要望に合う素材を適切に選び出すには, 色彩 に対する知識とデザイナーの選定能力に依るところ が大きい. したがって, デザイナー間での作業効率 の差は非常に大きい. そこで, 長年の経験や勘に基 づいて効率良く作業を行っているデザイナーが, 発 注者からの言葉や色彩による要望を受けて, どのよ うな点に注目して画像や写真を適切に選び出してい るかについて, 聞き取り調查を行った. 聞き取り調 查は, 印刷会社で印刷物の製造に 20 年以上携わっ てきた 3 人の熟練デザイナーに対して行った.

この調査の結果, 次のような点に注目して画像や 写真に対してデザイナーは印象を持ち, 適切に選び 出し作業を行っていることが明らかになった.まず, 画像や写真を構成している色彩の種類を調べてい る. 次いで, それらの色彩の中から, その画像や写 真の印象を与えると考えられる代表色を決定してい る. 代表色は, 画像の全体面積に対して, 抽出され た色彩の面積割合の大きい方から順に決定されてい 3. 代表色の個数については, 対象の画像に応じて 決定している. デザイナーは, 決定した代表色とデ ザイナー自身が色彩に関して持っている知識とを照
合して，画像の印象を与えている.

この調査結果から, デザイナーは画像から代表色 を抽出し, それらの代表色とデザイナーが持つ色彩 と印象語に関する知識とを照合して印象語を付与し ていることが判明した. したがって, 害際の画像を 処理して, 上述した物理量を求めることができれば, デザイナーと同等の能力を持つシステムを開発でき る可能性がある.

この調査に基づいて, 次の諸点を考慮してシステ ムを作る必要がある.

I . 印象語と関わりの深い色彩に関する情報をデ ータベース化すること.

II. 画像や写真から代表色を抽出すること.

III. 代表色に基づいて画像や写真に印象語を付与 すること.

以下の章においてこの点を順次検討していく.

\section{3. 色彩と印象語との関係}

ここでは, 2 章の I で示した印象語と関わりの深 い色彩について述べる. 前述したように, 栗田ら(1) 及び田中ら (2) は, それぞれ 30 種及び 180 種 $^{(4)}$ の 印象語を用いた。本方法では, 色彩と印象語との関 係を与えるデータとして文献(3)を利用する. 文献(3) では, 印象語として 160 種の語彙が用いられ，160 種の印象語ごとに関わりの深い色彩が登録されてい る. 文献(3)と文献(4)に共通する印象語の個数は 101 種であった. 相当な個数の印象語が共通であること がわかる. 表 1 には, 160 種の印象語並びにそれぞ れの印象語に登録されている色彩の個数（色数）を 示している. 登録されている色数は印象語ごとに異 なっている. 色数の最大值は 24 個, 最小値は 7 個 である. 文献(3)に登録の色数は, 文献(4)より多く, 色彩が整理されている. 文献(3)では, 印象語ごと に登録されている色彩を 3 色組, 4 色組, 5 色組な ど, 色彩を組み合わせて配色することにより, それ ぞれの印象語を付与できることを示している. ただ し, 任意の色彩は複数個の印象語に登録されている ので, 色彩の組み合わせによる配色と印象語との関 係は一対一ではなく, 同じ配色でも異なった印象を 与えることもある.

デザイン画像の印象語の個数について前述の 3 人 のデザイナーに対して聞き取り調查を行った. 調査 の結果, 印象語の個数として前述の 30 種では少な いが, 160 種であれば充分であることを確認した.

本方法では, 上述した文献(3)のデータをコンピ ュータに登録して用いる. 
Table 1 Used impression words and number of colors registered to each of the impression words.

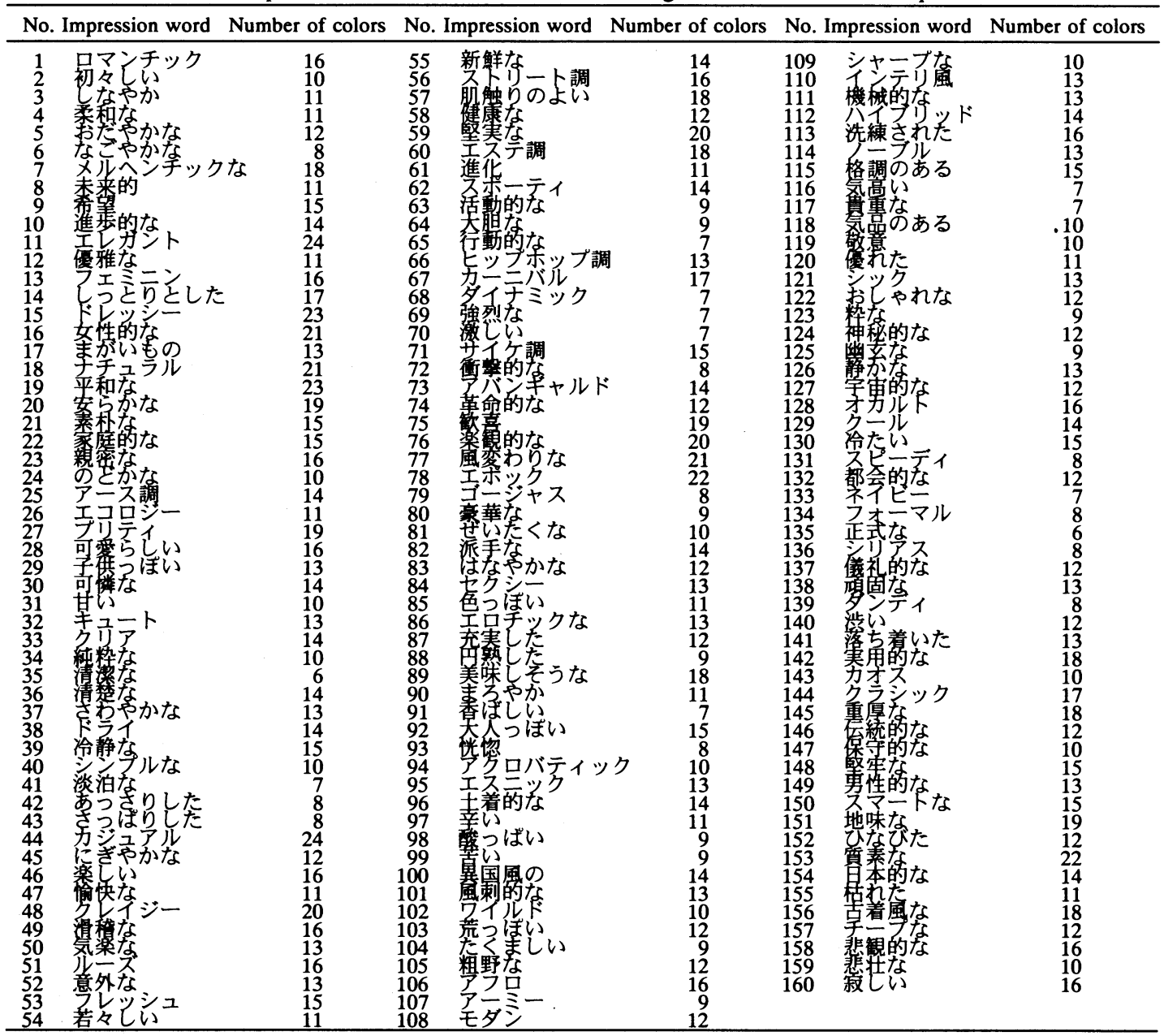

\section{4. 画像の代表色の抽出}

ここでは， 2 章の II で示した画像や写真から代表 色を抽出する方法について述べる. 本方法では, Lab 色空間でのクラスタリングにより画像から代表色を 抽出する方法について述べる.

4.1 Lab色空间を用いた色表現 コンピュータ 上では, 画像は RGB 形式で色彩を表現する. 画像 の $\mathrm{R}$ 值, $\mathrm{G}$ 值, B 值が, それぞれ 256 階調（0か ら 255 の整数値）であるならば，その画像は約 1677 万種の色彩を表現できる. 本方法では, 色彩に基づ いて画像に印象語を付与することを目的としている ので, 正確な色差を得る必要がある. RGB 色空間 は直交座標系ではないので, 正確に色差を求めるこ とができない。したがって, RGB 值を用いて画像
から正確に代表色を抽出することはできない.

高橋ら ${ }^{(5)}(6)$ や堀田ら (7) は, Lab 色空間を用い れば正確に色差を求めることができることを示して いる. そこで，本方法では Lab 色空間を用いて色 彩を表現する．ここでは，(R,G,B)值を(L,a,b)值に変 換するために, Connolly $5^{(8)}$ の方法を用いる. $(\mathrm{R}, \mathrm{G}, \mathrm{B})$ 值の $(\mathrm{L}, \mathrm{a}, \mathrm{b})$ 值への変換は以下の式(1)から式 (4)を用いて行う.

$$
\begin{aligned}
& r=\frac{100}{255} \times \mathrm{R}, \quad g=\frac{100}{255} \times \mathrm{G}, \quad b=\frac{100}{255} \times \mathrm{B} \\
& {\left[\begin{array}{l}
\mathrm{X} \\
\mathrm{Y} \\
\mathrm{Z}
\end{array}\right]=\left[\begin{array}{lll}
0.4303 & 0.3416 & 0.1784 \\
0.2219 & 0.7068 & 0.0713 \\
0.0202 & 0.1296 & 0.9393
\end{array}\right]\left[\begin{array}{l}
r \\
g \\
b
\end{array}\right]}
\end{aligned}
$$




$$
\begin{aligned}
& \mathrm{L}=116 f\left(\frac{\mathrm{Y}}{\mathrm{Y}_{0}}\right)-16 \\
& a=500\left[f \frac{\mathrm{X}}{\mathrm{X}_{0}}-f \frac{\mathrm{Y}}{\mathrm{Y}_{0}}\right] \\
& b=200\left[f \frac{\mathrm{Y}}{\mathrm{Y}_{0}}-f \frac{\mathrm{Z}}{\mathrm{Z}_{0}}\right]
\end{aligned}
$$

$$
\text { ただし, } f(q) \text { は }
$$

$$
\begin{array}{ll}
f(q)=\sqrt[3]{q} & q>0.008856 \\
f(q)=7.787 q+\frac{16}{116} & q \leqq 0.008856
\end{array}
$$

であり， $\mathrm{X}_{0}, \mathrm{Y}_{0}, \mathrm{Z}_{0}$ は, 式(2)において $(r, g, b)=$ (100,100,100) の時の値である.

$4 \cdot 2$ クラスタリングによる代表色抽出 ここ では, Lab 色空間でのクラスタリングにより画像か ら代表色を抽出する方法について述べる. クラスタ リングは, 特徽空間に写像された複数の点を, 距離 の近いものどうしでまとめてグルーブ化する処理で ある.したがって, 画像のすべての N 個の画素を Lab 值で表現し，Lab 色空間でのクラスタリングを行え ば, いくつかのグループ(クラスタ)が形成され，そ れぞれのクラスタの代表值を画像の代表色として捉 えることができる.

本方法では, クラスタリング手法の一つである $\mathrm{K}$ 平均法 ${ }^{(9)}$ を用いる. K 平均法では，はじめにクラ ス夕の個数を決定する必要がある. ここで, 100 種 のデザイン画像を用意し，それぞれの画像を構成す る色彩の個数を調查した. 調查の結果, 色彩の個数 の平均值は 8.4 個, 最大値は 16 個であった. した がって, クラスタの個数は最大 16 個であれば充分 であると判断されるので, クラス夕数 $\mathrm{K}$ の值を 16 とする. $\mathrm{K}$ 平均法によるクラスタリングは以下の手 順に従って行う。

(1)16 個のクラスタ $\mathrm{C}_{1} \sim \mathrm{C}_{16}$ の中心の值を初期化 する.

(2)画素 $\mathrm{P}_{\mathrm{i}}(i=1, \cdots, \mathrm{N})$ とクラスタ $\mathrm{C}_{1} \sim \mathrm{C}_{16}$ の中心の 值との距離を調べ, 画素 $\mathrm{P}_{\mathrm{i}}$ を最小の距離にあ るクラスタ $\mathrm{C}_{j}(1 \leqq j \leqq 16)$ に属させる.

(3)クラスタ $\mathrm{C}_{j}$ の中心の值を, 現時点でクラスタ C に属する全ての画素の平均をとることによっ て更新する.

(4)すべての N 個の画素に対して(2)(3)の処理を行 ったならば(5)へ，それ以外の時は $i$ を 1 増やし て(2)へ戻る.

(5)最初(1)で設定した 16 個のクラスタ中心の值 が, (2)〜(4)までの処理によって更新された場
合, 現在のクラスタ中心を初期のクラスタ中心 とみなし， $i=1$ として(2)に戻る. 一方，全く 更新されなかった場合は全ての処理を終了す る.

4·3 クラスタの初期值設定法 前述したクラ スタリングの手順(1)では, 16 個のクラスタ $\mathrm{C}$ 、 $\mathrm{C}_{16}$ の中心の值を初期化する必要がある. ここでは, 以 下の(1)及び(2)に示す $2 つ$ 初期值設定法を用いて クラスタリングする実験を行い, 実験結果よりクラ ス夕の初期值設定法を決定する.

(1)RGB の色表現において, R 值, G 值, B 值と して 0，128 及び 255 の 3 つの值を組み合わせ て作る 27 個の色彩の中から任意に取り出した 16 個の色彩を, 前述の式(1)〜式(4)を用いて L 值, $\mathrm{a}$ 值, $\mathrm{b}$ 值に変換し, それぞれの Lab 值を 16 個のクラス夕の中心の初期値とする方法.

(2)入力画像の全画素の Lab 值を求め, Lab 色空 間においてヒストグラムを作成する. そのヒス トグラムの中で密度の高い領域を探し, 密度の 高い領域の Lab 值を用いて 16 個のクラスタの 中心の初期值とする方法.

(2)の方法では, Lab 色空間において作成するヒス トグラムでの密度の高い領域の探索は次のようにし て行う. Lab 色空間の L 軸を 20 個, a 軸を 40 個, b 軸を 40 個に等しく分割することにより， Lab 色空 間を 32000 個の小領域に分割する. 32000 個の小領 域のなかで以下に示す二つの条件をともに満たすす ベての小領域の中心をクラスタの初期値として採用 する.二つの条件は，対象となる小領域に含まれる 画素数が指定した最小の画素数より多く，かつそれ に隣接する小領域の画素数より多いことである. 上 述の条件を満たす小領域の個数が 16 個を越える場 合は画素数の多い小領域から順に用い, 16 個に満 たない場合は残りのクラスタの初期值は(1)の方法 により設定する.

上述の(1)と(2)で示した初期值設定法を用いて図 1 の画像に対してクラスタリングを行う。図1の画 像の 5 つの領域の RGB 值と Lab 值を表 2 に示す. ここで, 図 1 の画像に対して上述した(1)及び(2)の 方法によりクラスタの初期值を設定して, クラスタ

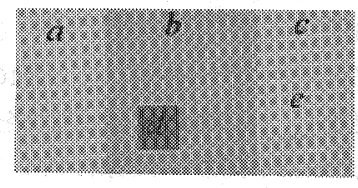

Fig.1 Image with 5 colors. 
Table 2 Data of 5 colors in Fig. 1.

\begin{tabular}{cccccccc}
\hline Region & R & G & B & L & a & b & Number of pixels \\
\hline a & 240 & 133 & 137 & 82.7 & 21.6 & 7.0 & 840 \\
b & 144 & 141 & 193 & 80.2 & 6.3 & -14.0 & 1370 \\
c & 184 & 141 & 185 & 82.0 & 13.4 & -9.0 & 800 \\
d & 248 & 0 & 0 & 53.9 & 79.6 & 67.6 & 110 \\
e & 248 & 205 & 0 & 91.0 & -10.9 & 86.6 & 120 \\
\hline
\end{tabular}

Table 3 Clustering result by method (1).

\begin{tabular}{crrrc}
\hline No. & R & G & B & Number of pixels \\
\hline 1 & 158 & 141 & 190 & 2170 \\
2 & 240 & 133 & 137 & 840 \\
3 & 248 & 205 & 0 & 120 \\
4 & 248 & 0 & 0 & 110 \\
\hline
\end{tabular}

Table 4 Clustering result by method (2).

\begin{tabular}{rrrrr}
\hline No. & R & G & B & Number of pixels \\
\hline 1 & 144 & 141 & 193 & 1370 \\
2 & 240 & 133 & 137 & 840 \\
3 & 184 & 141 & 185 & 800 \\
4 & 248 & 205 & 0 & 120 \\
5 & 248 & 0 & 0 & 110 \\
\hline
\end{tabular}

リングを行った. その結果を表 3 と表 4 に示す. 表 3 より, (1)の方法では 16 個のクラスタのうち 4 個 のクラスタにデータが集まり, 残りの 12 個のクラ スタには 1 個もデータが属さなかった.したがって, 4 種の色彩が抽出されている.この結果の理由は, Lab 色空間において領域 $\mathrm{b}$ と領域 $\mathrm{c}$ は近い距離にあ るので, クラスタリング処理により領域 $\mathrm{b}$ と領域 $\mathrm{c}$ は同一のクラスタと見なされたためと考えられる. したがって, 表 3 の番号 1 の色彩は, 領域 $\mathrm{b}$ と領域 $\mathrm{c}$ を混ぜ合わせた色彩として抽出されている.

一方, 表 4 の結果より，(2)の方法では 16 個のク ラスタのうち 5 個のクラスタにデータが集まった.

つまり 5 種の色彩が抽出されている.この 5 種の色 彩の值は, 表 2 に示した 5 種の色彩の值と同じであ る.したがって，正しく目的の色彩が抽出できてい ることがわかる.

上述の結果より，(2)で示した方法によりクラス 夕の初期值を設定することが適切であると判断され る.そこで，本方法では，(2)の方法を用いてクラ スタの初期値を設定する.

4.4 画像の代表色抽出实験 ここでは, 上述 したクラスタリング手法を用いて画像の代表色を抽 出する実験を行う。実験に用いる画像を図 2 に示す. 上述した方法により図 2 の画像に対してクラスタリ ングを行った結果を表 5 に示す. 5 種の色彩を抽出

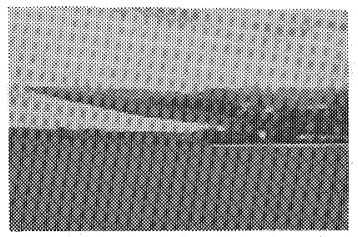

Fig.2 Objective image.

Table 5 Clustering result in Fig.2.

\begin{tabular}{crrrcc}
\hline No. & R & G & B & Number of pixels & Percentage (\%) \\
\hline 1 & 95 & 90 & 131 & 4713 & 45.4 \\
2 & 204 & 217 & 234 & 3603 & 34.8 \\
3 & 77 & 101 & 66 & 1077 & 10.3 \\
4 & 192 & 171 & 129 & 600 & 5.8 \\
5 & 16 & 28 & 18 & 377 & 3.7 \\
\hline
\end{tabular}

していることがわかる. 表 5 の抽出結果についてデ ザイナーに対して調査した結果, デザイナーが代表 色として考える色彩と同じ色彩を本方法が抽出して いることを確認している. また, 図 2 に示した画像 の代表色の個数について，デザイナーに対して調査 した. その結果, 面積割合の大きいほうから 3 色, つまり, 番号 1 , 番号 2 , 番号 3 の 3 色を代表色と していることが判明した. したがって，画像の代表 色は, クラスタリングの結果より, 面積割合の大き い方から順に選定すればよいという結論を得る.

\section{5. 印嗮語付与システム}

ここでは，2 章の亚で示した代表色に基づいて画 像や写真に印象語を付与する方法について述べる. 本方法では，前述した $\mathrm{K}$ 平均法によるクラスタリ ングを用いて画像から代表色を抽出し，その代表色 と 160 種の印象語ごとに登録されている色彩との間 に距離を求める式を定義し，その距離を用いて印象 語を付与する方法を提案する.

まず, 画像から抽出する代表色の個数について検 討する. 103 種の画像を用意し; それらの画像に対 してデザイナーが決定する代表色の個数について調 査した. その結果を表 6 に示す. 代表色の個数は, 3 色，4色及び 5 色であり，103 種の画像のうち， それぞれの画像の個数は 71 個(69\%), 18 個(17.4 \%), 14 個(13.6\%)であった.この調查結果から， デザイナーは画像を構成する色彩の内容に応じて, 代表色の個数を 3 色，4色及び 5 色と区別している ことがわかる.

そこで, デザイナーが代表色の個数を決定してい 
る要因について聞き取り調査した. その結果, 画像 の全体面積のある一定割合以上の面積を占める色彩 の組み合わせを代表色としていることが判明した. したがって, 画像の全体面積のある一定割合以上の 面積を占める色彩を調べ，その結果に基づき代表色 の個数を 3 色， 4 色及び 5 色と決定すれば良いと考 えられる.

表 6 において, 代表色数ごとに画像の全体面積に 対して代表色が占めた面積の割合を求め，その面積 割合の平均値を求めた結果を表 7 に示す. 代表色数 が 3 色， 4 色及び 5 色のいずれの場合においても， 面積割合の平均値は約 85 \%であることが判明した. つまり，全体面積の $85 \%$ を占める色彩を面積割合 の大きい方から順に選ぶことにより画像の代表色の 個数を自動的に決定できると考えられる.

したがって, 画像の代表色の個数は, クラスタリ ングの結果を利用して, 画像の全体面積の $85 \%$ を 占める色彩を面積割合の大きい方から順に選ぶこと により決定する.

画像から抽出した $n$ 個の代表色と 160 種の印象語 との間の距離の求め方について述べる. まず, $n$ 色 の代表色を $\mathrm{X}=\left(x_{1}, \cdots, x_{1}\right)$ とし, ある印象語の登録 色の中から抽出した任意の $n$ 色を $\mathrm{Y}=\left(y_{1}, \cdots, y_{n}\right)$ とする時, $\mathbf{X}$ と $\mathbf{Y}$ との間の距離を次のように定義 する.

$$
d(\mathbf{X}, \mathbf{Y})=\min \left(\sum_{i, j=1}^{n} f\left(x_{i}, y_{j}\right)\right.
$$

ただし，

$$
f(x, y)=\sqrt{\left(\mathrm{L}_{x}-\mathrm{L}_{y}\right)^{2}+\left(a_{x}-a_{y}\right)^{2}+\left(b_{x}-b_{y}\right)^{2}}
$$

$\mathrm{L}, a_{x}, b_{x}$ 及び $\mathrm{L}_{y}, a_{y}, b_{y}$ は, それぞれ色 $x$ 及び色 $y$ の Lab 值を表している.

Table 6 Number of main colors determined by designer in 103 images.

\begin{tabular}{ccc}
\hline Number of main colors & Number of images & Percentage(\%) \\
\hline 3 & 71 & 69.0 \\
4 & 18 & 17.4 \\
5 & 14 & 13.6 \\
\hline
\end{tabular}

Table 7 Average area rate which main colors occupy in image.

\begin{tabular}{cc}
\hline Number of main colors & Average area rate(\%) \\
\hline 3 & 84.1 \\
4 & 85.3 \\
5 & 85.0 \\
\hline
\end{tabular}

表 1 に示したように，印象語ごとに登録されてい る色数 $m$ は異なっているが, その色数は $m>3$ であ る. したがって, $m$ 個の中から任意の $n$ 色を組み合 わせる配色の個数 $l$ は, ${ }_{m} \mathrm{C}_{n}$ 個であるので, 式(5)で は ${ }_{m} \mathrm{C}_{n}$ 個の距離が求められる.

上述のことから, ある印象語 $k$ に対して求められ る距離を $d\left(\mathbf{X}, \mathbf{Y}_{k l)}\left(l=1, \cdots, C_{n}\right)\right.$ と記述する. そこで, $d\left(\mathbf{X}, \mathbf{Y}_{k 1}\right)$ を用いて, 印象語ごとに最小距離 $\mathrm{D}_{k}$ 及び平 均距離 $\mathrm{V}_{\mathrm{k}}$ を式(7)及び式(8)より求める.

$\mathrm{D}_{k}=\min d\left(\mathrm{X}, \mathrm{Y}_{k l}\right) k=1, \cdots, 160 l=1, \cdots{ }_{m} \mathrm{C}_{n}$

$$
\mathrm{V}_{k}=\frac{\sum_{l=1}^{m \mathrm{C}_{n}} d\left(\mathrm{X}, \mathrm{Y}_{k l}\right)}{{ }_{m} \mathrm{C}_{n}} \quad k=1, \cdot, 160 \quad l=1, \cdots,{ }_{m} \mathrm{C}_{n}
$$

ここで, 最小距離 $\mathrm{D}_{\mathbf{k}}$ 及び平均距離 $\mathrm{V}_{\mathbf{k}}$ を用いて印 象語の順位を決める. まず, 最小距離 $\mathrm{D}_{k}$ の小さい 順に印象語に対して 1 位から 160 位までの順位を付 ける. 最小距離 $\mathrm{D}_{k}$ の值が同じ場合には, 平均距離 $\mathrm{V}_{k}$ の値の小さい順に並べることにより 160 種の印象語 に対して 1 位から 160 位までの順位を付ける. した がって, 順位が 1 位の印象語をその画像に付与すべ き印象語の第 1 候補とする. 以下, 順次 2 位の印象 語を第 2 候補, 3 位の印象語を第 3 候補とする. た だし, 代表色の個数が 6 以上となる場合は， 5 色配 色を用いて距離を求める.

ここで, 上述の方法により, 図 2 の画像に対して 160 種の印象語との距離を求めた結果を表 8 に示 す. 最小距離と平均距離の結果に基づき, 印象語の 順位を決定した結果を表 9 に示す. 図 2 の画像に対 してデザイナーが付与する印象語について調查し た. その結果, デザイナーは“エレガント”を印象

Table 8 Minimum and average distances every 160 impression words.

\begin{tabular}{rlcc}
\hline No. & Impression word & Minimum $\left(\mathrm{D}_{\mathrm{k}}\right)$ & Average $\left(\mathrm{V}_{\mathrm{k}}\right)$ \\
\hline 1 & ロマンチック & 33 & 70.7 \\
2 & 初々しい & 62 & 70.5 \\
3 & しなやか & 56 & 65.0 \\
4. & 柔和な & 61 & 70.9 \\
5 & おだやかな & 51 & 73.1 \\
6 & なごやかな & 51 & 70.7 \\
7 & メルへンチックな & 33 & 59.9 \\
8 & 未来的 & 38 & 60.9 \\
9 & 希望 & 33 & 61.2 \\
10 & 進歩的な & 33 & 60.3 \\
& · & $\cdot$ & $\cdot$ \\
158 & 悲観的な & 33 & 66.5 \\
159 & 悲壮な & 59 & 105.2 \\
160 & 寂しい & 33 & 59.6 \\
\hline
\end{tabular}


Table 9 Impression words by the system for Fig. 2

\begin{tabular}{clcc}
\hline Order & Impression word & Minimum $\left(\mathrm{D}_{\mathrm{k}}\right)$ & Average $\left(\mathrm{V}_{\mathrm{k}}\right)$ \\
\hline 1 & エレガント & 19 & 67.8 \\
2 & 古着風な & 20 & 44.3 \\
3 & 質素な & 22 & 55.3 \\
4 & 風変わりな & 22 & 80.1 \\
5 & 重厚な & 24 & 97.8 \\
\hline
\end{tabular}

語として付与した。この結果は，本方法が出力した 第 1 候補の印象語と一致する結果を得ている.

\section{6. 印象語付与実験}

ここでは，5章で示した方法を用いて画像に印象 語を付与する実験について述べる，実験では，本方 法が付与する結果と前述した 3 人の熟練デザイナー の中から任意に選んだ 1 人のデザイナーによる結果 との比較を行う. 実験のために 103 種の画像を用意 した．画像の一例を図 3 に示す.

まず，本方法により 103 種の画像の代表色の個数 を決定した. その結果を表 10 に示す. 次いで, 103 種の画像に対してデザイナ一が付与した印象語と本 方法が出力した印象語の候補と一致するときの順位 を調べた. その結果を表11 に示す．表11の結果よ り，本方法は，デザイナーが付与する印象語と一致 する印象語を第 5 候補までの印象語として出力して いることがわかる．第 5 候補の印象語とデザイナ一 のものとが一致した場合の実験画像を調べたとこ ろ, 代表色数はすべて 3 色であり，3色の色彩のう ち 1 色の面積が他の 2 色の面積より極端に小さかっ た.この場合，本方法は 3 色の代表色を用いて印象 語を付与したが, デザイナーは面積の大きい 2 色に 重きをおいて印象語を付与したことがわかった.

ここで，画像の面積割合の大きい方から３色だけ を代表色として用いて，前述の 103 種の画像に印象 語を付与する実験を行った. デザイナーが付与した 印象語と一致する印象語を出力する順位を調べた. その結果を表 12 に示す. 代表色として 3 色だけを 用いる方法では，第 1 から第 5 候補までの印象語と デザイナーが付与した印象語と一致する画像の個数

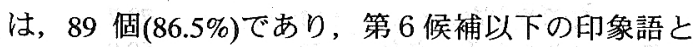
一致する個数は 14 個(13.5\%)であった.

3色だけを用いる方法により付与した印象語の候 補順位が，本方法により代表色が 3 色から 4 色及び 3 色から 5 色へ代わることにより候補順位がどのよ うに変動するかについて調べた。その結果を表 13 に示す. 本方法を用いて代表色が 3 色から 4 色及び

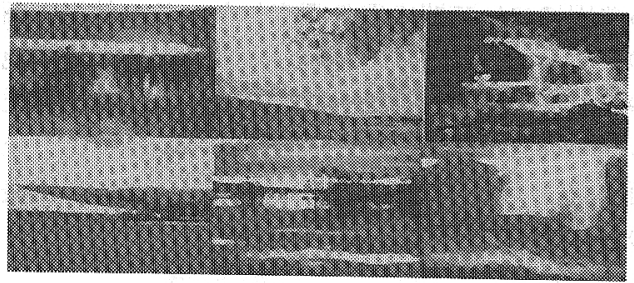

Fig.3 Examples of used images in experiment.

Table 10 Number of images for different numbers of main colors in 103 images.

\begin{tabular}{cc}
\hline Number of main colors & Number of images \\
\hline 3 & 48 \\
4 & 21 \\
5 & 34 \\
\hline
\end{tabular}

Table 11 Order in which proposed method gives the same impression word as designer.

\begin{tabular}{cccc}
\hline Order & Frequency & Percentage(\%) & Total $(\%)$ \\
\hline 1 & 51 & 49.5 & 49.5 \\
2 & 31 & 30.1 & 79.6 \\
3 & 10 & 9.7 & 89.3 \\
4 & 5 & 4.9 & 94.2 \\
5 & 6 & 5.8 & 100.0 \\
\hline
\end{tabular}

Table 12 Order in which only 3 color method gives the same impression word as designer.

\begin{tabular}{cccc}
\hline Order & Frequency & Percentage $(\%)$ & Total(\%) \\
\hline 1 & 42 & 40.8 & 40.8 \\
2 & 23 & 22.3 & 63.1 \\
3 & 12 & 11.7 & 74.8 \\
4 & 5 & 4.9 & 79.7 \\
5 & 7 & 6.8 & 86.5 \\
under 6 & 14 & 13.5 & 100.0 \\
\hline
\end{tabular}

Table 13 Change of order between proposed method and only 3 color method in the same impression word given.

\begin{tabular}{lcc}
\hline Change in order & \multicolumn{2}{c}{ Change in number of main colors } \\
\cline { 2 - 3 } & 3 to 4 & 3 to 5 \\
\hline Rise & 11 & 18 \\
Even & 6 & 9 \\
Down & 4 & 7 \\
\hline
\end{tabular}

3色から5色へ代わることにより，それぞれ 11 個 及び 18 個の画像について候補順位が上がったこと がわかる. 上述の結果から，代表色の個数を 3 色に 固定する方法よりも，画像を構成する色彩の面積割 
合に応じて代表色の個数を 3 色， 4 色及び 5 色とす る本方法が印象語をより適切に付与できることがわ かる.

本実験では，本方法による結果と 1 人の熟練デザ イナーによる結果とを比較した．実験に用いた 50 \%の画像において本方法が付与した第 1 候補の印象 語とデザイナーのものとが一致する結果を得た.こ の一致度は, 文献(10)によれば高いと評価できるこ とが示されている. 本稿で聞き取り調查した他の 2 人の熟練デザイナーについても同じ程度のデザイン 能力をもつことから, 同様の実験を行うならば, 同 じ程度の結果を得られることが推測できる.

したがって，本方法では，画像を占有する色彩の 面積割合から代表色として 3 色，4色及び 5 色を用 いて印象語を付与している. 本方法を用いれば, デ ザイナーと一致する印象語を付与できると言える.

\section{7. 結言}

印刷物で用いられるデザイン画像に対して印象語 を付与する方法について述べた．本方法では，画像 を代表する色彩をクラスタリング手法を適用して正 確に抽出し，抽出した代表色とあらかじめ登録した 印象語と関係の深い色彩との間の距離を求め, その 距離に基づいて印象語を付与する方法を提案した. 特に, 画像の全体面積の 85 \%を占める色彩をクラ スタリング結果より抽出し, それらの色彩を代表色 として用いることにより，デザイナーが付与する印 象語と同じ印象語を付与できた．本方法を用いて実 際の画像に対して印象語を付与する実験を行い, 実 験結果を通して本方法の有効性を示した. 今後は, さらに多くの画像に対して実験を重ね、本方法の性 能の向上について検討していく予定である.

さいごに，本研究を進めるに当たり，貴重なご意
見を戴いた九州芸術工科大学浦浜喜一教授並びに井 上光平助手に対して感謝の意を表す.

\section{文献}

(1) 栗田多喜夫, 加藤俊一, 福田郁美, 坂倉あゆみ : “印象語による絵画データベースの検索”, 情 報処理学会論文誌, 33-11, (1992), 1373-1383.

(2) 田中昭二, 石若通利, 井上正之, 井上誠喜 : “ 自然画像への印象キーワード自動付加に関する 一考察”, 電子情報通信学会技術報告, HIP96-20, (1996), 19-24.

(3) 南雲治嘉 : カラーイメージチャート, グラフィ ック社, (1999), 12-174.

(4) 小林重順 : カラーイメージスケール, (2001), 2-159.

(5) 高橋圭子, 阿部圭一：“ISODATA クラスタリ ング法を用いたカラー画像の領域分割”, 電子情 報通信学会論文誌, J82-D-II, No.4, (1999), 751-762.

(6) 高橋圭子, 阿部圭一: “クラスタリング(ISODA TA 法) に適切な色空間の比較”, 電子情報通信 学会技術報告, PRMU96-63, (1996), 23-28.

(7) 堀田裕弘, 宮原誠, 小谷一孔: “均等色空間に 基づくカラー画像の領域分割”, 電子情報通信学 会論文誌, J74-D-II , No.10, (1991), 1370-1378.

(8) C. Connolly and T. Fliess:"A study of efficiency and accuracy in the transformation from RGB to CIELAB Color space",IEEE Transactions on Image Processing, 6-7, (1997),1046-1048.

(9) 安居院猛, 長尾智晴 : C 言語による画像処理入 門, 昭晃堂, (2000), 106-124.

(10)小林重順：景観の色とイメージ, ダヴィッド社, (1997), 22-24. 